Catalogue of New Double Stars.-Prof. R. G. Aitken has just published, in No. 50 of the Lick Observatory Bulletins, a sixth list of new double stars discovered by him during the systematic search he has prosecuted since 1899 . The present list contains 216 new pairs, none of which appear in Prof. Burnham's General Catalogue. These doubles were discovered with the 36 -inch and 12 -inch refractors, $6 x$ of them-several of which are separated by less than $\mathrm{o}^{\prime \prime} \cdot 25$-being credited to the smaller instrument. About 30 per cent. of the included stars have distances under $\mathrm{o}^{\prime \prime} .50,50$ per cent. under $\mathrm{I}^{\prime \prime} \cdot \mathrm{O}$, and in more than 72 per cent. the distance of separation is less than $2^{\prime \prime} \cdot 0$. The numbers assigned to the stars in the present list are in continuation of those in the former lists, and the star places are given for the epoch of $1900 \cdot 0$.

\section{NOTES ON THE HISTORY OF THE METRICAL MEASURES AND WEIGHTS.}

A TRADITION exists in this country that towards the end of the eighteenth century the French Government invited the English Government to cooperate in forming a joint committee for the measurement of the seconds pendulum at the latitude of $45^{\circ}$, which was to be used as a standard of length, and from this length a universal system of measures and weights was to be derived; the English Government having declined to accede to the request, the French savants took the matter in hand and devised the metre and its derivatives. Although this tradition existed, it did not appear to be easy to obtain documentary evidence with regard to it, and it was quite natural that Mr. Alexander Siemens, who was interested in the subject, should apply to the Royal Society in the expectation that some record of the transaction would be found in the minutes of council; these were searched, but without result.

Hearing accidentally of the application, I thought that I could at once place my hand on a reference that would settle the question, but found myself mistaken, so I concluded that I must have heard the statement made by one of my former professors, Hofmann or Frankland.

Having succeeded ultimately in tracing the early history of the negotiations and allied matters, it is possible that the following notes may be not without interest.

Inquiries amongst several friends being without avail, it struck me that there might be some record at the Foreign ()ffice that would throw light on the subject; I therefore wrote to Lord Cranborne, then Under Secretary for Foreign Affairs, asking if the index of their foreign correspondence mentioned the matter. He replied that the correspondence was not indexed, and that it was now at the Record Office; the was also good enough to obtain for me a permit to search the original documents. Before I had proceeded very far in the search, Dr. R. T. Glazebrook suggested a reference (t) the book by Méchain and Delambre, "Base du Système mètrique Décima1," Paris, I806. In the introduction, or "Discours préliminaire," there occurs on p. r4 an extract from a decree of the National Assembly asking the King to write to His Britannic Majesty requesting him to submit the decree of the National Assembly to the English Parliament.

In vol. xxxiv. of the Foreign Office French Correspondence, January to June, 1790 , at the Record Office, is a letter from the French Ambassador in England, the Marquis de la Luzerne, enclosing a copy of the decree of the National Assembly to the Duke of Leeds, the Secretary if State for Foreign Affairs. ${ }^{1}$

\section{The Marquis de la Luzerne to the Duke of Leeds.}

"Portman Square le 22 Mai, I79o.

"Le $M$ is de la Luzerne a 1 'honneur de faire bien des compliments à Monsieur le Duc de Leeds et se conforme aux ordres de sa Cour en lui envoyant ci-joint la copie d'un decret de l'Assemblée Nationale concernant les poids et mesures. Ces ordres lui prescrivent de faire au Ministère de sa Majesté Britannique les demandes qui y sont indiquées, et de 1'assurer que le Roi son Maître verra avec

1 The orthography and the accentuation of the original documents are there followed.

$$
\text { NO. 1792, VOL. 69] }
$$

satisfaction que Sa Majesté Britannique les juge de nature à être prises en considération.

" Décrét de 1'Assemblée Nationale du $8 \mathrm{Mai}$, I790.

" L'Assemblée Nationale desirant faire jouir à jamais la France entière de l'avantage qui doit résulter de l'uniformité des poids et mesures, et voulant que les rapports des anciennes mesures avec les nouvelles soient clairement determinés et facilement saisis, décrète que Sa Majesté sera suppliée de donner des ordres aux administrateurs des divers départemens du Royaume, à fin qu'elles se procurent et qu'elles se fassent remettre par chacune des Municipalités comprises dans chaque département, et qu'elles envoyent à Paris, pour être remis au secrétaire de l'Académie des Sciences, un modèle parfaitement exact des différens poids et des mesures élémentaires qui y sont en usage.

"Décreté ensuite que le Roi sera également supplié d'écrire à Sa Majesté Britannique, et de la prier d'engager le Parlement d'Angleterre à concourir avec l'Assemblée Nationale à la fixation de l'unité naturelle de mesures et de poids: Qu'en conséquence, sous les auspices des deux nations, des commissaires de l'Académie des Sciences de Paris pourront se réunir en nombre égal avec des Membres choisis de la Société Royale de Londres, dans le lieu qui sera jugé respectivement le plus convenable, pour déterminer à la latitude de quarante cinq degrés, ou toute autre latitude qui pourroit être préférée, la longueur du pendule, et en déduire un modèle invariable pour toutes les mesures et pour les poids; Qu'après cette opération faite avec toute la solemnité nécessaire, Sa Majesté sera suppliée de charger l'Académie des Sciences, de fixer avec précision pour chaque municipalité du Royaume, les rapports de leurs anciens poids et mesures avec le nouveau modèle, et de composer ensuite pour l'usage de ces municipalités des livres usuels et élémentaires où seront indiquées avec clarté toutes ces proportions.

"Décrète en outre que ces livres élémentaires seront addressés à la fois dans toutes les municipalités pour y être repandues et distribuées: Qu'en même tems il sera envoyé à chaque municipalité un certain nombre de nouveaux poids et mesures, les quels seront délivrés gratuitement par elles à ceux que ce changement constitueroit dans les dépenses trop fortes: Enfin que six. Mois seulement après cet envoi, les anciennes mesures seront abolies et remplacées par les nouvelles.

"Collationnée à l'original par nous Président et Secrétaire de l'Assemblée Nationale à Paris le 9 Mai 1790. Signé Gouttes, curé d'Argilliers, Président, L'Abbé Collaud de la Salcette, de Champeaux Palame, Le Cte de Crillon, Chabrond, de la Revelliere, de 1'épaux, et de fermon, Secrétaires."

It will be observed that this decree does not specifically state that a new standard is to be introduced, but that the existing standards are to be corrected by one that has been compared with the length of the seconds pendulum.

Delambre states (loc. cit.) that the above decree was sanctioned on August 22, and that the Academy of Sciences nominated a commission consisting of MM. Borda, Lagrange, Laplace, Monge and Condorcet. He does not say that any reply was received from the English Government, and there is not any mention in the papers at the Record Office before the end of August that any reply had been sent.

It was considered probable that the reply, if any, might have been forwarded through the French Ambassador without having been recorded at the Foreign Office, or that the draft of the letter might have been lost. Sir Eric Barrington, Private Secretary to the Marquess of Lansdowne, very obligingly obtained, through the British Embassy at Paris, a copy of a letter from the Duke of Leeds to the Marquis de la Luzerne, dated December 3, 1790. On further search the draft of this letter was found in vol. xxxv. of the Foreign Office French Correspondence, July to December, I790, at the Record Office, together with the note from the Marquis de la Luzerne reminding the Duke of Leeds of his letter of May 22.

The Marquis de la Luzerne to the Duke of Leeds.

“ M. De la Luzerne a l'honneur de faire bien des compliments à Monsieur le Duc de Leeds et de lui rapeller qu'il a eu cetui de lui addresser, Le 22 mai dernier, par ordre 
de sa cour, un office dont l'objet était d'inviter le Gouvernement Britannique à vouloir bien concourir avec le Gouvernement de France, à prendre les mésures qui seraient jugées respectivement les plus convenables, pour fixer l'unité naturelle dès mesures et des poids. Si Monsieur le Duc de Leeds avait la bonté de faire connaître à M. de la Luzerne, les intentions de Sa Majesté Britannique sur ce point et de la mettre en état de satisfaire aux nouveaux ordres qu'il reçoit de sa cour, M. de la Luzerne lui aura beaucoup d'obligations.

"Portman Square, Le $309^{\text {bre }}$ 179o."

The Duke of Leeds to the Marquis de la Luzerne.

"Le Duc de Leeds fait bien ses Complimens à Monsieur Le Marquis de la Luzerne, et a 1'Honneur d'informer Sun Excellence que les Mesures, dont Elle fait mention dans sa Note d'Hier, pour fixer 1'Unité des Mesures et des Poids, doivent necessairement rester pour la Consideration du Parlement.

"A Whitehall, ce I Decre, I79o."

The same to the same.

"A Whitehall, ce 3 Décembre, 1790.

"Monsieur,

“ Je n'ai pas manque de rendre compte au roi de la note dont Votre Excellence m'a honoré du 22 mai, renfermant la copie d'un Décrêt de l'Assemblée Nationale, concernant 1'Unité de Mesures et de Poids, qu'on souhaitoit de fixer, en concurrence avec le Parlement d'Angleterre; et j'ai 1'honneur d'informer Votre Excellence qu'aiant, par ordre du Roi, fait faire des perquisitions à ce sujet, it paroit que l'affaire a été agitée dans la Chambre des Communes, vers la fin du dernier Parlement, mais qu'aucune proposition de la Chambre n'a été faite en oonséquence.

"Il a souvent été question d'un tel arrangement parmi nos économistes publics, mais le projet a paru exposé à tant de difficultés que son accomplissement, tout désirable qu'il pourroit être, a été regardé comme presque impraticable.

"Il est superflu, Monsieur, d'assurer Votre Excellence de nouveau de la satisfaction avec laquelle le Roi sera disposé en tout tems de coopérer avec Sa Majesté très Chrètienne à tout ce qui pourroit être utile aux intérêts des deux royaumes,

"J'ai l'honneur d'être, avec la considération la plus distinguée,

$$
\begin{gathered}
\text { " De Vonsieur, } \\
\text { " "le très humble et } \\
\text { " très obéissant serviteur } \\
\text { "[Signé] LeEds." }
\end{gathered}
$$

A Son Exce Mons. le Marquis De la Luzerne, \&c. Consequence. On a écrit en marge-"Envoyé copie à M. Dupont, le 9 janvier, I791.- "Envoyé copie au Comité des Poids et Mesures, le 25 prairial."

Archives des Affaires Etrangères. Correspondance d'Angleterre. Supplément, t. 18, pièce 66, fol. 353 . Original.

The reference to the action taken in the previous Parliament is doubtless the motion made on February 5, 1790 by Sir John Riggs Miller,

"That the clerks of the market of the different cities and market towns throughout England and Wales, and the town of Berwick upon Tweed, and the clerks of the different counties of the same, do forthwith make out and transmit to the sheriffs of the respective counties in which the said towns are situated, returns of the different weights and measures now in use in their respective cities and market towns, as well as specifications and descriptions of any particular commodities that are bought and sold by any customary denominations or proportions of weight and measure, as far as such have come under their observation." "That the said order be sent to the sheriffs of the several counties in England and Wales, and be by them transmitted to the clerks of the markets in their respective counties; and that the said sheriffs do return to the Clerk of the House, to be by him laid before the House, the returns they shall receive from the clerks of the markets."

The speech by Sir John Riggs Miller is of much interest, No. 1792 , VOI. 691 and describes the confused condition in which the weights and measures in use in England were at that time. He said "He should not impose upon the House for the present an attention to a philosophical discussion, which would better suit a more advanced stage of the investigation, but content himself with merely acquainting them at that time, that the vibration of a pendulum would, he hoped, prove such a standard." The resolutions he proposed were unanimously agreed to. (Parliamentary Register, vol. xxvii. [marked 44 on the binding of the British Museum copy], 179o, pp. 41-48. Parliamentary History, vol, xxviii., 1816, cols. 315323.)

On April I, I79o, the House of Commons ordered that a committee be appointed to consider the several returns which shall have been or shall be made to the orders of the House of the $5^{\text {th }}$ day of February last respecting the different weights and measures now in use in the several cities and markets throughout England and Wales and the town of Berwick upon Tweed, and to examine and report on the same, with their observations and opinions thereon, to the House.

Committee appointed accordingly.

The list of the members of the committee contains fortythree names, as well as all the members for Bristol, Liverpool, Hull, Glasgow, Lynn and Yarmouth, all the Knights for Shires, Gentlemen of the Long Robe, and Merchants in the House (Commons Journal, vol. xlv. p. 359).

On April 13, I790, Sir John Riggs Miller made another speech to the House, in which he said that he had received a letter from the Bishop of Autun (M. Talleyrand de Périgord, afterwards Prince Talleyrand) encouraging him in his attempts to improve the weights and measures, and saying that " he took the hint of making his proposition to the National Assembly of France from what had been lately submitted to the British Parliament upon the same subject."

On this occasion Sir John Riggs Miller entered more fully into the question of standards, which he thought should be obtained from some natural length or some property of matter. He suggested that a certain number of drops of water or alcohol at a certain temperature might be used as a measure of weight, and that the length of the side of a cube which would contain the standard weight might be taken as a standard of length; as another standard, the distance through which a body would fall in one second; as another, the length of a degree of a great circle on the earth, but he thought that it would not be possible to measure this with sufficient accuracy; and lastly, what he calls the London pendulum of 39.126 inches.

Amongst general qualities that a standard should possess he stated, "It is desirable that its denomination should be in tens, to give it the advantage of whole numbers, or decimal fractions."

On the same day the reports of comnittees made in $175^{8}$ and 1759 on the original standards were ordered to be referred to the committee appointed on April I. (Parliamentary Register, vol. xxvii. [marked 44 on the binding of the British Museum copy] pp. 395-403. Parliamentary History, vol. xxviii., 1816 , cols. 639-649.)

This committee did not report; it is doubtful if it ever met, for a committee on standards of weights and measures which reported on July I, 1814 , states that the minutes of the proceedings of the committee of 1790 could not be found.

At the British Museum there is a volume of "Political Tracts," I789-179o, which contains a pamphlet by Sir John Riggs Miller giving his speeches in the House of Commons, and several documents, amongst which are copies of letters from the Bishop of Autun (a copy of the same pamphlet is in the library of the Royal Institution). The letter to which he referred in his speech is as follows:-

\section{The Bishop of Autun to Sir John Riggs Miller.}

"Paris, 28 Mars, r79o.

“J'ai appris, Monsieur, que vous avies presenté au Parlement d'Angleterre un beau travail sur la Reduction des Mesures. J'ai cru devoir faire une Proposition sur le même sujet à notre Assemblée Nationale; je m'empresse di vous l'addresser, il me paroit digne de l'Epoque actuelle que les deux Nations se concertent pour la fixation d'une mesure 
invariable, et quelles consultent ensemble la Nature pour arriver à ce résultat important.

"Si cette Idée vous paroit juste, Monsieur, si vous pensés qu'un grand bien doit en resulter, c'est à vous qu'il appartient d'en assurer le succès, et j'ose vous le recommendér : trop long temps les deux Nations se sont devisées pour de vaines pretentions ou de Coupables Interets, il est tenıps que deux Peuples libres assoçient leurs efforts et leurs Travaux pour une Recherche utile au Genre Humain.

“J'ai l'honneur d'être avec des "Sentimens respectueux,

"Monsieur, votre très humble

"Et trés obeissant serviteur "L'Evec. D'Autun.

"To Sir John Riggs Miller, Bart.

"Member of the House of Commons, London."

(The English printer seems to have taken some liberties with the foreign language.)

Parliament was dissolved on June II, I79o, so the committee ceased to exist, and it appears that Sir John Riggs Miller was not re-elected in the next Parliament.

I have been unable to ascertain the date when the Bishop of Autun made his proposition to the National Assembly, and if, in doing so, he referred to the action taken in the House of Commons. In the pamphlet of Sir John Riggs Miller is a reprint of a paper which the Bishop of Autun sent to all the members of the National Assembly, with a note attached saying that he considered that it would be preferable to print his proposition than to make a speech on the subject.

This paper contains the following paragraph, when referring to the measurement of the pendulum :- "Il m'est impossible de douter que l'Angleterre, qui dans ce moment paroît vouloir s'occuper de la reduction de ses mesures, avertie par votre détermination et invitée par vous, ne se réunire à la France pour l'exécution d'une entreprise que nos relations de commerce doivent rendre commune et dont le résultat doit appartenir un jour au Monde entier."

It will be a surprise to many to learn that there was any connection, even of the remotest kind, between the action of the British House of Commons and the proposition which ultimately led to the metrical measures and weights.

The committee that was appointed by the French Academy o:1 August 22, 1790, reported on March 19, I791 ("Histoire de l'Académie Royale des Sciences,"' Année MDCCI.XXXVIII., published in 1791, pp. 7-16). The committee considered three proposed standards of length, the length of the seconds pendulum at the latitude of $45^{\circ}$, which was rejected in consequence of its involving the artificial element of time; the measurement of an arc of the equator, which was also rejected, because of the difficulties that would attend such an operation in an uncivilised country; and the measurement of an arc of the meridian, which was adopted, and the 10,000, oooth part of the quadrant was selected as the standard of length.

The account given by Delambre of the measurement of the arc of the meridian from Dunkerque to Barcelona is most interesting; he was commissioned to measure the northern section whilst Méchain undertook the southern portion. Delambre left Paris with orders from the King, and before long he found them of little use; he had a difficulty in obtaining money for the expenses of the work, and at one time he was dismissed, as it was thought that his opinions were not in accord with those prevalent in Paris. Later he was permitted to continue the undertaking. $\mathrm{He}$ found that many of the church towers and spires which had been used in the survey of 1740 , and which he intended employing again, had been destroyed; he could not use signal fires, for they were thought to be signals to the enemies of the country, and when he covered some of his stations with white sheets, so that they might be more visible at a distance, they were supposed to be standards of the counter revolution, and it was necessary to place blue and red bands on them to calm the suspicions of the populace. When Méchain had completed his work in Spain he was not allowed to return to Paris, and although he finished his portion of the survey, he died before the determination of the standards had been brought to a conclusion.
Notwithstanding all these adverse circumstances and disappointments, Delambre's account is remarkably free from bitterness.

It had been determined to submit the whole survey to a committee of foreign scientific men, so that it should have an international character, and the meeting was fixed for I5 vendémiaire an 7 (the 6th October, 1798); the survey, however, was not completed until about two months later. The account of the invitation to this final meeting is best given in Delambre's own words:-

'On a vu que le premier projet avoit été d'inviter la Société royale de Londres à concourir avec l'Académie des Sciences à la fixation de l'unité fondamentale; mais l'unité projetée étoit alors la longueur du pendule. La mesure de la méridienne étoit une entreprise bien plus considérable, et d'une trop longue durée pour qu'on pût se flatter de la voir terminer par les commissaires réunis des deux nations, lorsque tant de causes probables et prochaines pouvoit troubler la bonne intelligence entre leurs gouvernemens. L'événement ne prouva que trop tôt combien cette crainte étoit fondée. Mais les mesures terminées, avant d'en. déduire les conséquences, il n'y avoit plus aucun inconvénient, on devoit au contraire trouver un avantage réel, à soumettre le travail à l'examen de tous les savans de l'Europe; et toutes les puissances amies ou seulement neutres furent invitées à nommer des députés à ce congrès d'une espèce toute nouvelle." (Méchain and Delambre, "Base du Système mètrique Décimal," Paris, I806. Tome i. “Discours préliminaire," pp. $85-86$.)

"Les savans étrangers venus pour prendre part à ces travaux étoient MM. Æneae et van Swinden, députés bataves; M. Balbo, député du roi de Sardaigne, remplacé depuis par M. Vassali Eandi, envoyé par le gouvernement provisoire du Piémont; M. Bugge, député du roi de Danemarck; MM. Ciscar et Pédrayés, députés du roi d'Espagne; M. Fabbroni, député de Toscane; M. Franchini, député de la République romaine; M. Mascheroni, député de la République cisalpine; M. Multedo, député de la République ligurienne, et $M$. Trallès, député de la République helvétique" (loc. cit. p. 92).

At that time England could not have been considered one of "les puissances amies," for war was declared by France against England in 1793, and continued for nearly nine years.

It has been the custom to discredit the Royal Society with having instigated the refusal of the French invitation, but there is no indication whatever that the matter was at any time referred to the society. The council minutes do not contain any mention of the invitation, and if the society had formally or informally suggested or approved of the refusal, it is inconceivable that the Duke of Leeds, who was at the time a member of the council, although a not very regular attendant at the meetings, would have omitted to mention such a support of his action. With regard to the absence of any English men of science on the last committee of revision, it seems certain, from Delambre's statement, that an invitation was not sent, and the minutes of the council of 1798 and 1799 are silent on the subject.

Without the kind assistance of others it would have been impossible for me to have obtained the information above given, and I take this opportunity of tendering my sincere thanks to the Marquess of Salisbury, Sir Eric Barrington, Sir Courtenay Ilbert, Dr. R. T. Glazebrook, the officials of the Royal Society and of the Public Record Office, for their help, and lastly to my former colleague, Prof. Alfred Lodge, who first put me on the right track by furnishing dates which much assisted the search.

Herbert McLeod.

\section{UNIVERSITY AND EDUCATIONAL} INTELLIGENCE.

CAMBRIDGE.-The Sedgwick prize in geology is awarded to H. H. Thomas, B.A., Sidney Sussex College.

Z. U. Ahmad, B.A., Trinity College, has been elected to the Isaac Newton studentship in physical astronomy.

The Medical College, Lahore, has been added to the list of recognised schools of medicine.

No. 1792, VOL. 69] 